\section{Jurnal Mitra Pendidikan (JMP Online)}

URL : http://e-jurnalmitrapendidikan.com
JMP Online

Vol. 4, No. 12, 823-835

(C) 2020 Kresna BIP. e-ISSN 2550-0481 p-ISSN 2614-7254

\title{
STRATEGI VIRAL-DESI UNTUK MENINGKATKAN PEMAHAMAN PENGGUNAAN KARTU SUARA DALAM SISTEM DEMOKRASI INDONESIA BAGI SISWA SMALB EMPAT LIMA BABAT
}

\author{
Vetra El Rahma
}

SLB Empat Lima Babat

INFORMASI ARTIKEL

Dikirim : 20 Desember 2020

Revisi pertama : 23 Desember 2020

Diterima : 29 Desember 2020

Tersedia online : 09 Januari 2021

Kata Kunci: Strategi Video Tutorial dan Demonstrasi, Kartu Suara, Sistem

Demokrasi

Email: vetraelrahma0677@gmail.com
ABSTRAK

Pelaksanaan Pemilu bersifat secara LUBER (Langsung, Umum, Bebas dan Rahasia), diselenggarakan secara umum/serentak tidak membedakan kondisi fisik seseorang apakah dalam keadaan sehat maupun sakit, keadaan normal ataupun dishabilitas, Bebas dalam memilih tanpa ada paksaan dan bersifat rahasia. Tantangan kami sebagai guru PPKn di SLB Empat Lima Babat adalah siswa SMALB tunagrahita belum mengetahui cara mencontreng dengan benar. Skor Pada pra siklus sebesar 24, pada siklus I skor rata-rata 52, kemudian penulis melanjutkan tindakan perbaikan di siklus ke II skor rata-rata 80, sesuai dengan KKM yang ditentukan. Dengan demikian "Strategi Viral Desi untuk meningkatkan pemahaman penggunaan kartu suara dalam sistem demokrasi Indonesia bagi siswa SMALB Empat Lima Babat Kecamatan Babat Kabupaten Lamongan. 


\section{PENDAHULUAN \\ Latar Belakang}

Pemilu atau singkatan dari Pemilihan Umum adalah PelaksanaanPesta demokrasi rakyat untuk menentukan dan mengisijabatan kepemimpinan suatu organisasi, dimulai dari jabatan eksekutif / presiden, legislatif / DPR (Dewan Perwakilan Rakyat mulai dari pusat sampai daerah, pemilihan Gubernur, pemilihan wali kota, pemilihan Bupati, sampai pemilihan kepala desa. Semua tak lepas dari peran serta rakyat sebagai penentu utama, karena suara dari rakyat itulah yang akan menentukan calon pemimpin di masa itu.

Di negara Indonesia Pelaksanaan Pemilu bersifat secara LUBER JURDIL Langsung, Umum, Bebas, Rahasia jujur dan adil) dikandung maksud bahwa calon pemimpin dipilih secara langsung oleh rakyat tidak boleh diwakilkan, diselenggarakan secara umum berartisemua warga negara Indonesia yang sudah memenuhi syarat usia 17 tahun diberikan hak suara tanpa membedakan suku, ras, gendre, kondisi apakah dalam kedaan sehat, sakit, normal ataupun disabilitas, Bebas dalam artian rakyat bebas memilih calon pimpinan tanpa ada paksaan,bersifat rahasia sebab diberikan bilik suara tempat yang semi tertutup tanpa diketahui orang lain yang secara pribadi rakyat memutuskan untuk mencontreng calon yang dipilih, suai dengan Jujur dan adil pemilu dilaksanakan sesuai kehendak hati nurani dan peserta pemilu diperlakukan sama tidak ada pengistimewaan atau diskriminasi.

Pemerintah telah tegas melalui Undang-Undang No 7 tahun 2017 tentang pemilihan umum, UU nomor 19 tahun 2011 tetang Ratifikasi Konvensi PBB mengenai hak-hak penyandang Disabilitas, UU no. 8 tahun 2016 tentang penyandang Disabilitas, dan UU nomor 18 tahun 2014 tentang kesehatan jiwa, bahwa dalam pasal 5 UU Pemilihan umum tegas sekali disebutkan bahwa penyandang disabilitas yang memenuhi syarat mempunyai kesempatan yang sama sebagai pemilih, sebagai calon anggota DPR, Sebagai calon anggota DPD, Sebagai calon presiden/wakil dan sebagai penyelenggara pemilu, prinsipnya semua penyandang disabilitas harus diberi akses yang setara untuk bersama-sama ikut berpartisipasi dalam kehidupan politik.

Fakta yang terjadi di lapangan tentang pelaksanaan Pemilu, tidak sedikit anak-anak dishabilitas yang tidak mendapatkan kartu suara padahal umur mereka sudah mencapai 17 tahun, sebagai syarat utama warga negara untuk mengikuti pelaksanaan pemilu dan memberikan suara kepada calon yang dipilihnya, terlebih anak-anak disabhilitas dengan keterbelakangan mental (lamban belajar, Down Syndrome, Autis, ADHD, Tuna daksa sedang dan Tuna ganda) seolah- olah mereka bukan bagian dari warga negara yang berhak menyalurkan aspirasi suaranya bahkan mungkin suara mereka tidak berarti sama sekali.

Untuk itu dalam penelitian ini penulis menggunakan Strategi VIRALDESI (Video Tutorial dan Demonstrasi) untuk membantu memberikan pemahaman pada anak-anak dishabilitas di SLB Empat Lima Babat yang sudah memasuki usia 17 tahun, sebagai syarat utama warga negara untuk mendapatkan kartu suara, dan menggunakan hak suara untuk memilih calon pemimpin, dengan memutarkan video pelaksanaan pemungutan suara lalu diterapkan melalui demontrasi di kelas secara sederhana dengan kegiatan melaksanakan pemilihan 
ketua kelas dengan menggunakan kaidah-kaidah pemilu LUBER, membimbing anak-anak dishabilitas bagaimana cara menggunakan kartu suara yang benar, cara membuka kartu suara, cara menusuk atau mencontreng calon pimpinan yang dipilih agar syah dan tidak salah dan melipat kembali dengan baik dan benar lalu terakhir memasukkan kartu suara di kotak suara.

Dampak yang ditimbulkan dari Strategi VIRAL-DESI adalah menjadikan pemahaman tersendiri bagi anak-anak disabilitas untuk mengikuti Pemilu dan memupuk rasa percaya diri bahwa anak-anak dishabilitas mempunyai hak yang sama untuk ikut memberikan kontribusi suara demi kemajuan bangsa.

\section{Rumusan Masalah}

Berdasarkan latar belakang yang sudah diuraikan di atas dapat dirumuskan permasalahan utama yaitu bagaimana meningkatkan pemahaman penggunaan kartu suara dalam sistem demokrasi di Indonesia untuk anak-anak disabilitas jenjang SMALB di SLB Empat Lima Babat?.

\section{Tujuan Penelitian}

Tujuan dari Strategi VIRAL-DESI (Video Tutorial dan Demontrasi) untuk anak-anak Tunagrahita jenjang SMALB adalah untuk meningkatnya pemahaman penggunaan kartu suara sehingga mampu menggunakann hak suara dalam sistem demokrasi di Indonesia.

\section{Manfaat Penelitian}

Dengan penelitian ini diharapkan bermanfaat bagi :

1. Guru, diharapkan guru mampu memberikan bimbingan kepada siswa-siswi SMALB yang sudah masuk usia 17 tahun dalam menggunakan hak suara pada sistem demokrasi di Indonesia, sehingga mampu meningkatkan pemahaman siswa-siswi SMALB dalam menggunakan kartu suara.

2. Siswa, mampu mencontreng dan melipat gambar pasangan calon pemimpin dengan baik dan benar, memberikan rasa percaya diri kepada siswa-siswi tunagrahita SMALB untuk ikut berpartisipasi dalam pelaksanaan sistem demokrasi di Indonesia.

\section{KAJIAN PUSTAKA}

\section{Sistem Demokrasi di Indonesia}

Demokrasi Indonesia dapat dipahami sebegai suatu mekanisme dan citacita hidup berkelompok dalam organisasi negara yang menurut Undang-Undang dasar 1945 disebut sebagai kerakyatan. Sistem demokrasi Indonesia adalah pemerintahan rakyat yang berdasarkan nilai-nilai falsafah Pancasila atau sistem pemerintahan yang dari, oleh, dan untuk rakyat yang sesuai dengan pandangan hidup bangsa Indonesia yaitu Pancasila.

Falsafah Pancasila tidak hanya mengandung nilai-nilai politik, ekonomi, sosial, dan budaya, namun juga mengandung nilai religius. Hal ini berarti bahwa nilai yang terkandung dalam Pancasila meliputi tanggung jawab kemanusiaan dan sekaligus terhadap Tuhan. Demokrasi Indonesia pada dasarnya telah dilkasanakan bangsa Indonesia sejak dulu sampai saat ini masih dapat dijumpai dalam 
kehidupan masyarakat Indonesia, khususnya dalam melaksanakan demokrasi secara musyawarah dan mufakat sesuai silai ke-4.

Dalam perjalanan sistem pemerintahan, Indonesia pernah melaksanakan sistem Demokrasi Terpimpin berdasarkan ketetapan MPRS No. VIII/MPRS/1965, pada saat pemberlakuan kembali Undang-Undang Dasar 1945 sesuai dekrit Presiden 5 Juli 1955. Namun berdasarkan ketetapan MPRS No. XXXVII/MPRS/1968 sistem Demokrasi Terpimpin dicabut karena bertentangan dengan Pancasila dan UUD 1945. Demokrasi Pancasila merupakan pengganti Demokrasi Terpimpin. Kemudian pelaksanaan Demokrasi Pancasila ini ditetapkan dan diatur berdasarkan ketetapan MPR No. 1/MPR/1978.

Dengan demikian sistem demokrasi Indonesia adalah sistem Demokrasi Pancasila yaitu sistem pemerintahan berdasarkan kedaulatan rakyat dalam bentuk musyawarah untuk mufakat dalam menyelesaikan permasalahan yang terjadi dalam kehidupan berbangsa dan bernegara, demi terwujudnya masyarakat yang adil dan makmur, baik material maupun spiritual yang dilandasi nilai-nilai dasar negara yaitu Pancasila.

\section{Asas Pemilu di Indonesia}

Asas Pemilu di Indonesia bersifat Luber Jurdil yaitu Langsung, Umum Bebas, Rahasia Jujur dan Adil

1. Langsung

Pemilih diwajibkan untuk memilih calon pemimpinnya secara langsung tidak boleh melalui perantara atau diwakilkan, asas ini bermanfaat untuk menghindari kecurangan atau iktikad buruk jual beli suara atau saling mempengaruhi.

2. Umum

Pelaksanaan pemilihan suara dilaksanakan secara menyeluruh kepada warga negara Indonesia yang sudah memenuhi syarat minimal usia 17 tahun dan terdaftar sebagai calon pemilih, tanpa memandang ras, suku, warna kulit, jabatan, gendre, kondisi fisik normal ataupun disabilitas. Ini sesuai dengan UU pasal 25 bahwa "Setiap warga negara harus mempunyai hak dan kesempatan yang sama untuk tanpa pemberdaan apapun dan tanpa pembatasan yang tidak wajar untuk berpartisipasi dalam menjalankan segala uurusan umum baik secara langsung maupun melalui wakil-wakil rakyat.

3. Bebas

Pemilu menganut asas Bebas, maksudnya adalah calon pemilih diberikan kebebasan untuk menentukan calon pemimpin yang dipilihnya tanpa ada tekanan, paksaan dan ancaman.

4. Rahasia

Bersifat rahasia maksudnya adalah hak suara yang diberikan kepada calon pemimpin tidak diketahui oleh siapapun, karena yang mengetahui adalah dirinya sendiri, bersifat privasi, tanpa ada campur tangan orang lain. 


\section{Jujur}

Pemilu menganut asas Jujur yaitu pelaksanaan pemilu dilakukan secara jujur tidak ada manipulasi data saat penghitungan suara, rakyat memiliki hak penuh atas suara yang diberikan tanpa ada yang memaksakan kehendak.

6. Adil

Adil berarti tidak ada pembedaan perlakuan peserta pemilu, menurut derajat, martabat, jabatan, semuanya diberikan kesempatan yang sama sesuai antrian, terkecuali bagi orang lansia, sakit keras, orang disabilitas yang mengalami gangguan mental sekiranya memerlukan perlakuan khusus dan sudah disepakati oleh panitia di Tempat penyelenggaraan Pemilu (TPS) tersebut.

\section{Dasar Hukum Pemilu Bagi Penyandang Dishabilitas}

Menurut Soekanwo, Ariani (2009:12)

1. Deklarasi universal hak-hak azasi manusia (1948) Pasal 21 (1) Setiap orang berhak turut serta dalam pemerintahan negaranya, secara langsung atau melalui wakil-wakil yang dipilih dengan bebas. (2) Setiap orang berhak atas kesempatan yang sama untuk diangkat dalam jabatan pemerintahan negaranya. (3) Kehendak rakyat harus menjadi dasar kekuasaan pemerintah; kehendak ini harus dinyatakan dalam pemilihan umum yang dilaksanakan secara berkala dan murni, dengan hak pilih yang bersifat umum dan sederajat, pemungutan suara secara rahasia ataupun dengan prosedur lain yang menjamin kebebasan memberikan suara.

2. Kovenan internasional tentang hak-hak sipil dan politik (iccpr) Pasal 25 Setiap warga negara harus mempunyai hak dan kesempatan, tanpa pembedaan apapun sebagaimana yang dimaksud dalam Pasal 2 dan tanpa pembatasan yang tidak layak, untuk:

a. Ikut serta dalam pelaksanaan urusan pemerintahan, baik secara langsung ataupun melalui wakil-wakil yang dipilih secara bebas;

b. Memilih dan dipilih pada pemilihan umum berkala yang murni, dan dengan hak pilih yang universal dan sama, serta dilakukan melalui pemungutan suara secara rahasia untuk menjamin kebebasan menyatakan keinginan dari para pemilih;

c. Memperoleh akses pada pelayanan umum di negaranya atas dasar persamaan dalam arti umum

3. Konvensi PBB tentang hak-hak penyandang disabilitas Konvensi Hak-Hak Penyandang Disabilitas (CRPD) yang baru saja diterapkan akhir-akhir ini mengkodifikasikan undang-undang internasional yang ada tentang hak-hak untuk berpartisipasi dalam politik dan kehidupan bermasyarakat serta penerapan hak-hak tersebut untuk partisipasi politik masyarakat penyandang disabilitas. Konvensi ini memberikan pedoman spesifik bagi negara anggotanya untuk memenuhi kewajiban mereka dalam memperkenalkan langkah-langkah positif untuk memastikan agar masyarakat penyandang disabilitas benar-benar memiliki akses yang efektif ke proses-proses politik. - Pasal 29: Partisipasi dalam Politik dan Kehidupan Bermasyarakat Negara-negara anggota menjamin 
hak-hak politik penyandang disabilitas dan memberikan kesempatan bagi mereka untuk menggunakan hak tersebut setara dengan anggota masyarakat lainnya, dan melaksanakan hal-hal berikut: (a) Memastikan bahwa penyandang disabilitas dapat berpartisipasi secara efektif dan sepenuhnya dalam politik dan kehidupan bermasyarakat setara dengan warga negara lain, secara langsung melalui perwakilan-perwakilan yang dipilih dengan bebas, termasuk hak dan kesempatan bagi penyandang disabilitas untuk memilih dan dipilih, antara lain, dengan cara: (i) memastikan bahwa prosedur, fasilitas dan materi pemilihan sudah tepat, dapat diakses dan mudah dimengerti serta digunakan; (ii) melindungi hak penyandang disabilitas dalam memberikan suara melalui kertas suara yang terjaga kerahasiaannya baik dalam pemilu maupun referendum publik, tanpa adanya intimidasi, dan hak untuk ikut serta dalam pemilu serta duduk di kursi pemerintahan dan melaksanakan fungsi-fungsi publik secara efektif diseluruh tingkat pemerintahan, memfasilitasi penggunaan teknologi baru yang dapat membantu bilamana diperlukan; (iii) Menjamin kebebasan untuk menyatakan kehendak sebagai pemilih dan oleh karena itu, jika perlu, berdasarkan permintaan mereka, diberi izin untuk dibantu dalam memilih oleh orang yang mereka tunjuk; (b) Secara aktif mengembangkan lingkungan dimasa penyandang disabilitas secara efektif dapat berpartisipasi penuh dalam kehidupan bermasyarakat, tanpa adanya diskriminasi dan berdasarkan atas azas kesetaraan dengan warga negara lain, serta mendorong partisipasi mereka dalam kehidupan bermasyarakat, termasuk diantaranya: (i) Partisipasi dalam kegiatan organisasi-organisasi dan asosiasi-asosiasi non pemerintah yang bergerak di bidang kehidupan bermasyarakat dan berpolitik negara serta dalam berbagai kegiatan dan administrasi partaipartai politik; (ii) Membentuk dan bergabung dengan organisasi-organisasi penyandang disabilitas untuk mewakili kaum penyandang disabilitas di tingkat internasional, nasional, regional dan daerah.

4. Undang-Undang Dasar Negara Republik Indonesia tahun 1945

5. UU RI Nomor 39 Tahun 1999 Tentang Hak asasi Manusia

6. UU RI Nomor 19 Tahun 2011 tentang Pengesahan Konvensi Mengenai Hakhak Penyandang dhisabilitas

7. UU RI Nomor 4 Tahun 1997tentang penyandang cacat

\section{Pengertian Anak Tunagrahita}

Anak tunagrahita adalah anak yang mengalami hambatan kecerdasan, sehingga secara umum kemampuan intelektualnya berada di bawah kemampuan anak anak pada umumnya.Anak tunagrahita adalah anak yang memiliki IQ kurang dari 70. Hallahan dalam Kustiatun (2018:31) mengemukakan bahwa mengestimasikan jumlah penyandang tunagrahita adalah 2,3\%, namun pada tahun 1984, Annual reprt to congres menyebutkan 1,92\% anak usia sekolah menyandang tunagrahita dengan perbandingan laki-laki $60 \%$ dan perempuan $40 \%$ atau 3:2.

Klasifikasian dari kemampuan kecerdasan ini dapat dilihat berdasarkan skor IQbaik dari standford-Binet maupun dari david Wechsler (dalam tabel Endang Rochyadi). Klasifikasi tersebut adalah : 
Anak dengan kemampuan intelegensi di atas rata-rata dibedakan menjadi :

1. Anak tunagrahita ringan (IQ 50-70)

2. Anak tunagrahita sedang (IQ 25-49)

3. anak tunagrahita berat (IQ 25- ke bawah)

4. Anak dengan kemampuan Intelegensi di atas rata-rata

Anak dengan kemampuan di atas rata-rata digolongkan menjadi 2 yaitu:

1. Genius, yaitu anak yang berkecerdasan di atas rata-rata

2. Tallented, yaitu anak yang memiliki keterbatakatan khusus

Karakteristik anak tunagrahita menurut Brown et al, Wolery \& haring dalam Mereka yang istimewa yang berkarya (Kustiatun Widianingsih : 2018 : 32) adalah :

1. Lamban dalam mempelajari hal-hal yang baru, mempunyai kesulitann dalam mempelajari pengetahuan abstrak, dan selalu cepat lupa.

2. Kesulitan dalam melakukan generalisasi dan mempelajari hal-hal yang baru

3. Kemampuan bicaranya sangat kurang bagi anak tunagrahita berat

4. Cacat fisik dan perkembangan gerak, Kebanyakan anak tunagrahita berat mempunyai keterbatasan dalam gerak fisik, ada yang tidak dapat berjalan, tidak dapat berdiri atau bangun tanpa bantuan. Mereka lambat dalam mengerjakan tugas-tugas yang sderhana, sulit menjangkau sesuatu, dan mendongakkan kepala.

5. Kurang dalam kemampuan menolong diri sendiri, anak tunagrahita berat sangat sulit untuk mengurus diri semdiri

6. Tingkah laku dan interaksi yang tidak lazim. Anak tunagrahita ringan dapat bermain bersama anak reguler, tetapi anak tunagrahita berat tidak mampu bersosialisasi dan mengikuti permainan di kelompok anak-anak reguler.

7. Tingkah laku kurang wajar yang terus menerus, misalnya : menggigit diri sendiri, membentur-benturkan kepalanya dan lain sebagainya.

\section{Strategi VIRAL-DESI (Video Tutorial dan Demonstrasi) Bagi Anak-Anak Disabilitas di SMALB Empat Lima Babat dalam Memberikan Hak Suara}

Strategi ini adalah rangkaian gambar hidup atau serangkaian kegiatan yang dikemas melalui media elektronik yang berfungsi untuk memberikan suatu informasi kepada masyarakat luas, agar memahami dan melaksanakan kegiatan yang akan berlangsung sesuai dengan petunjuk dan pedoman yang disajikan lewat video tutorial tersebut, cara agar masyarakat memahaminya yaitu dengan mensosialisasikan video tutorial melalui media elektronik yaitu TV, Youtube, IG, atau media yang lain.

Untuk siswa-siswi di SMALB (Sekolah Menengah Atas Luar Biasa) Empat lima Babat, penulis melalui Kegiatan Belajar Mengajar pada kelas X Tunagrahita, di KD 2.2 yang berbunyi : Mengamalkan sistem demokrasi di Indonesia", untuk itu penulis memperkenalkan tata cara pemilu dengan memutar video tutorial melalui LCD, secara berulang-ulang dengan menjelaskan maksud dan tujuan pelaksanaan pemilu. Guru Menjelaskan kepada anak-anak dan siswa dibimbing secara intensif bagaimana memasuki bilik suara yang sudah ditetapkan, cara membuka kartu suara, mencontreng pada salah satu gambar calon wakil rakyat hanya pada satu gambar atau di 
dalam gambar dan tidak boleh di luar gambar atau kedua gambar poto calon ditusuk semua, sehingga berakibat suara dinyatakan tidak sah, kemudian membimbing cara mencontreng dengan menusuk memakai alat tusuk yang sudah disiapkan di dalam bilik suara dan melipat kembali, lalu memasukkan kartu suara tersebut ke kotak suara.

Selanjutnya untuk menerapkan pelaksanaan demokrasi dengan asas Luberjurdil, penulis mengajak siswa SMALB untuk mengadakan pemilihan ketua kelas dengan menggunakan tata cara pemilu, yaitu siswa diberikan kesempatan untuk mencalonkan diri sebagai ketua kelas, lalu guru menentukan calon ketua kelas, kemudian membuat skenario kegiatan pemilihan ketua kelas dengan menggunakan asas Langsung, Umum, Bebas, Rahasia, Jujur dan Adil. Dengan demikian siswa-siswi SMALB Empat Lima Babat menjadi faham dan mengerti tata cara mengikuti pemilu, baik itu Pilpres, Pileg, Pilgub, Pilbup maupun Pildes, mereka akan memiliki sikap percaya diri yang penuh untuk memberikan hak suara dan ikut berkontribusi kepada bangsa untuk menentukan calon-calon wakil rakyat.

\section{METODE PENELITIAN}

\section{Tempat, Subjek dan Waktu Penelitian}

Penelitian dilakukan di SLB Empat Lima Babat, Jl. Kauman No.42 Babat, Kabupaten Lamongan. Obyek penelitian ini adalah Peserta Didik Tunagrahita jenjang SMALB yang sudah berusia 17 tahun dan belum memahami cara penggnaan hak suara dalam sistem demokrasi di Indonesia dengan jumlah 5 siswa.

Pelaksanaan penelitian ini membutuhkan 2 siklus, dimulai pada tanggal 05 Oktober sampai 31 Oktober 2020. Jam pelajaran sesuai dengan jam pelajaran di masa pandemi covid-19 yaitu mengurangi 10 menit per mata pelajaran menjadi 30 menit per satuan pelajaran,dilakukan setiap hari Senin (pada pembelajaran Tematik)yaitu mulai pukul 08.30- 09.30 WIB. Adapun rincian jadwal pelaksanaan persiklus sebagai berikut :

a. Pelaksanaan rencana pembelajaran pra siklus dilaksanakan pada tanggal 05 Oktober 2020

b. Pelaksanaan rencana tindakan siklus I dilaksanakan pada tanggal 12 Oktober 2020

c. Pelaksanaan perbaikan siklus II dilaksanakan pada tanggal 19 Oktober 2020

\section{Teknik Pengumpulan Data}

Dalam setiap penelitian disamping penggunaan metode yang tepat, diperlukan pula kemampuan memilih bahkan juga menyusun alat pengumpul data yang relevan. Teknik dan alat pengumpul data yang tepat dalam suatu penelitian akan memungkinkan tercapainya pemecahan masalah secara tepat dan selanjutnya memungkinkan proses generalisasi terhadap hasil penelitian yang obyektif. Sehubungan dengan hal tersebut, maka teknik dan alat pengumpul data dalam Penelitian Tindakan Kelas ini adalah sebagai berikut :

1. Teknik observasi, yaitu pengamatan yang dilakukan oleh pembimbing untuk mencatat gejala-gejala yang terjadi pada siswa pada saat pelaksanaan kegiatan belajar mengajar dengan menggunakan panduan yang telah dibuat. 
2. Teknik pemberian tes, yaitu cara mengumpulkan data yang bersifat kuantitatif untuk mengetahui tingkatan atau derajat keberhasilan guru sebelum dan sesudah pelaksanaan tindakan.

\section{Teknik Analisa Data}

Setelah data terkumpul dari setiap kegiatan proses pembelajaran selanjutnya data tersebut dianalisis, yaitu data yang dikumpulkan dari obervasi dan pemberian tes kepada subyek penelitian dan data lainnya yang mendukung pada pelaksanaan siklus I dan siklus II. Data dianalisis secara partisipatif dengan menggunakan teknik prosentase dilihat dari kecenderungan yang terjadi dalam pembelajaran selama penelitian berlangsung terutama yang berhubungan dengan aktivitas anak pada penggunaan kartu suara pada pelajaran PPKn. Data yang dianalisis itu adalah :

1. Implementasi Video Tutotial dan demonstrasi (Viral Desi) dalam meningkatkan pemahaman penggunaan kartu suara dalam sistem demokrasi di Indonesia .Kualitas proses pembelajaran guru, melalui panduan video tutorial yang disajikan guru melalui proyektor dan aktivitas guru dalam mengelola pembelajaran pada siklus I dan siklus II.

2. Kemampuan belajar siswa, dengan melihat hasil perbandingan belajar pada siklus I dan siklus II, dengan cara memprosentasekan dan hasil rata-rata dalam satu kelas, dianalisis dengan perhitungan statistic persentase yaitu :

Keterangan :

$$
\mathrm{X} \%=\mathrm{n} / \mathrm{Nx} 100 \%
$$

$\mathrm{X} \%=\quad$ Persentase hasil hitung

$\mathrm{n} \quad=\quad$ Jumlah siswa yang memperoleh nilai tertentu

$\mathrm{N} \quad=\quad$ Jumlah seluruh siswa

(Ali $2001: 18$ )

Menurut Miles dan Huberman dalam Iskandar (2009 : 108), mengatakan bahwa Analisis data Penelitian Tindakan Kelas (PTK) mempergunakan kata-kata yang selalu disusun dalam sebuah teks yang didiskripsikan. Interprestasi dan penafsiran data dilakukan dengan mengacu pada rujukan teoritis yang berkaitan dengan permasalahan penelitian. Analisis data yang digunakan melalui 3 langkah kegiatan yaitu : reduksi data, display/penyajian data dan pengambilan kesimpulan.

Dengan demikian dapat digaris bawahi bahwa rata-rata data yang sudah dianalisis dengan perhitungan statistik frekuensi dapat memberikan gambaran aktivitas tentang kesimpulan-kesimpulan yang dapat diambil dalam penelitian ini.

\section{Deskripsi Siklus}

Perencanaan (Planning) dengan rincian sebagai berikut :

a. Membuat skenario pembelajaran dengan menggunakan pendekatan eksperiental learning (belajar melalui pengalaman).

b. Membuat instrument observasi untuk melihat sampai sejauh mana proses pembelajaran telah dapat berjalan.

c. Membuat penilaian untuk mengukur sejauh mana materi pembelajaran dapat disampaikan guru dan dipahami oleh siswa 
Gambar 1. Siklus Tindakan dalam Penelitian Tindakan Kelas

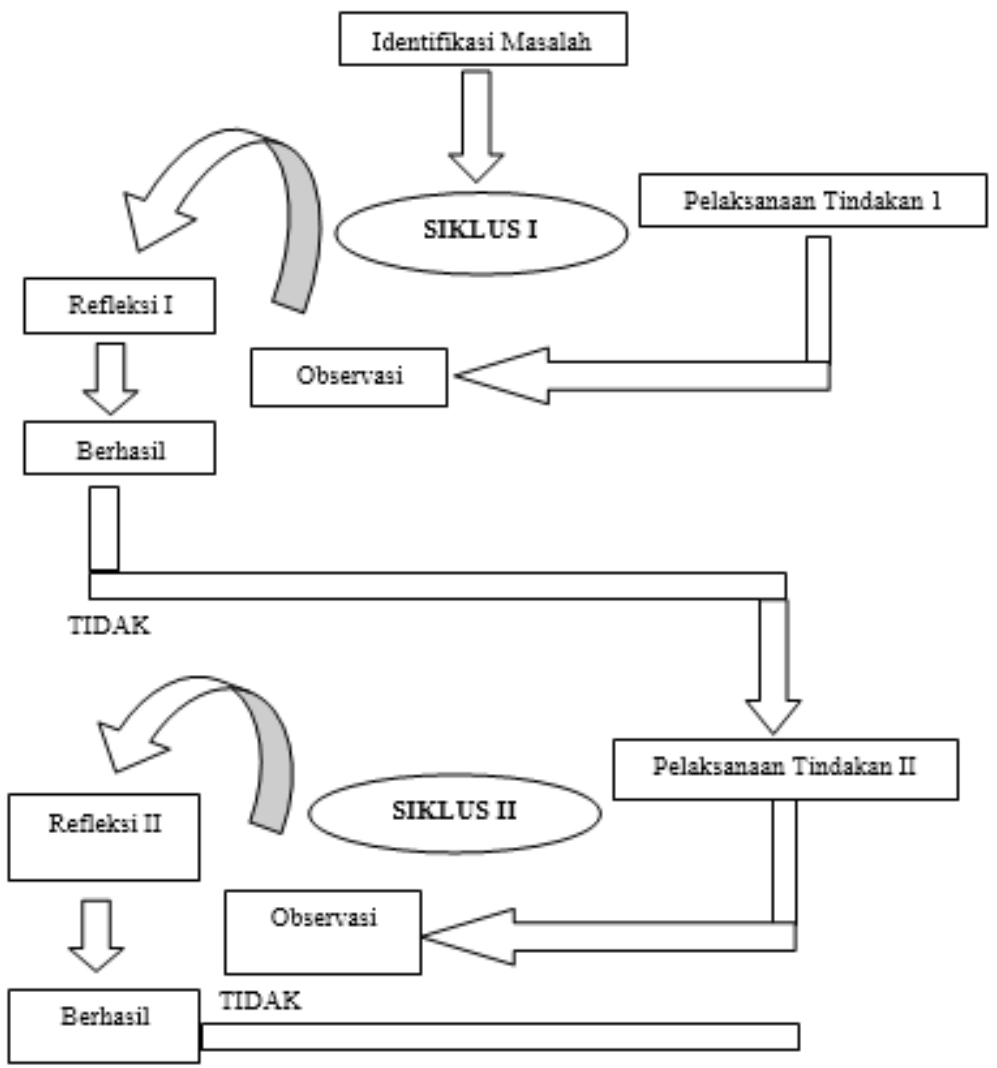

Sumber : Data Primer (2020)

\section{HASIL PENELITIAN DAN PEMBAHASAN \\ Hasil Penelitian}

Observer dalam pelaksanaan Penelitian Tindakan Kelas ini adalah guru PPKn kelas XI SMALB Empat Lima Babat Lamongan yang melakukan pengamatan selama berlangsungnya proses pembelajaran, dan memberikan masukan kepada peneliti sebagai bahan untuk evaluasi dan melakukan refleksi.

\section{Pra Siklus}

Guru menerangkan materi PPKn KD. 4.2 tentang Pelaksanaan Sistem Demokrasi di Indonesia, pada hari Senin tanggal 05 Oktober 2020, kemudian peneliti meminta kepada peserta didik untuk memilih pasangan calon pemimpin dengan mencontreng pada gambar/nomor urut pasangan calon, dan menjelaskan cara melipat kartu suara dengan baik dan benar. Diperoleh data sebagai berikut:

Tabel 1. Rekapitulasi Hasil Ketepatan Mencotreng Siswa pada Kartu Suara Pra Siklus

\begin{tabular}{|c|c|c|c|c|c|}
\hline \multirow{2}{*}{ NO } & \multirow{2}{*}{ Nama Siswa } & \multirow{2}{*}{ L/P } & \multicolumn{2}{|c|}{ Ketepatan Mencontreng } & \multirow{2}{*}{ Nilai } \\
\cline { 4 - 5 } & & 1 Paslon & 2 Paslon & \\
\hline 1 & Indra & L & $\sqrt{ }$ & & 80 \\
\hline 2 & Syahrul & L & & $\sqrt{ }$ & 10 \\
\hline
\end{tabular}


Lanjutan Tabel 1. Rekapitulasi Hasil Ketepatan Mencotreng Siswa pada Kartu Suara Pra Siklus

\begin{tabular}{|c|c|c|c|c|c|}
\hline \multirow{2}{*}{ NO } & \multirow{2}{*}{ Nama Siswa } & \multirow{2}{*}{ L/P } & \multicolumn{2}{|c|}{ Ketepatan Mencontreng } & \multirow{2}{*}{ Nilai } \\
\cline { 4 - 5 } & & 1 Paslon & 2 Paslon & \\
\hline 3 & Fida & $\mathrm{P}$ & & $\sqrt{ }$ & 10 \\
\hline 4 & Laila & $\mathrm{P}$ & & $\sqrt{ }$ & 10 \\
\hline 5 & Lala & $\mathrm{P}$ & & $\sqrt{ }$ & 10 \\
\hline \multicolumn{7}{|c|}{ Rata-rata } & $120 / 5 \times 100=24$ \\
\hline
\end{tabular}

Sumber : Hasil Penelitian, diolah (2020)

Keterangan:

1. Siswa mencontreng pada 1 gambar paslon dengan benar mendapat skor 80

2. siswa mencontreng pada 2 gambar paslon mendapat skor 10

Pada tahap Pra siklus hanya 1 anak yang mampu mencontreng 1 gambar pasangan calon pemimpin pada kartu suara dengan benar dan 4 anak masih mencontreng pada 2 gambar sekaligus pasangan calon. Sehingga skor akhir pada tahap Pra siklus adalah 24 nilai yang masih sangat rendah dari KKM yang diinginkan peneliti yaitu 80 , untuk itu peneliti merancang dengan tindakan penggunaan Strategi Viral Desi pada Siklus I.

\section{Siklus I}

Dalam kegiatan pembelajaran pada siklus I, peneliti menerangkan kembali tentang tata cara penggunaan kartu suara dengan memutarkan video tutorial tata cara pelaksanaan pemilu melalui youtobe yang dilaksanakan pada hari Senin 12 Oktober 2020. Baik peneliti maupun kolaborator mencatat segala aktifitas peserta didik Tunagrahita di kelas XI SMALB pada mata pelajaran PPKn dengan Materi pelaksanaan sistem demokrasi di Indonesia, dan diperoleh data sebagai berikut:

Tabel 2. Rekapitulasi Hasil Ketepatan Mencotreng Siswa pada Kartu Suara Siklus I

\begin{tabular}{|c|c|c|c|c|c|}
\hline \multirow{2}{*}{ No } & Nama & \multirow{2}{*}{ L/P } & \multicolumn{2}{|c|}{ Ketepatan Mencontreng } & \multirow{2}{*}{ Nilai } \\
\cline { 4 - 5 } & Siswa & & 1 Paslon & 2 Paslon & \\
\hline 1 & Indra & L & $\sqrt{ }$ & & 80 \\
\hline 2 & Syahrul & L & $\sqrt{ }$ & & 80 \\
\hline 3 & Fida & P & & $\sqrt{ }$ & 10 \\
\hline 4 & Laila & P & & $\sqrt{ }$ & 10 \\
\hline 5 & Lala & P & $\sqrt{ }$ & & 80 \\
\hline \multicolumn{7}{|c|}{ Rata-rata } & $260 / 5 \times 100=52$ \\
\hline
\end{tabular}

Sumber : Hasil Penelitian, diolah (2020)

Keterangan:

1. Siswa mencontreng pada 1 gambar paslon dengan benar mendapat skor 80

2. siswa mencontreng pada 2 gambar paslon mendapat skor 10

Pada tahap siklus Iterdapat 3 anak yang mampu mencontreng 1 gambar pasangan calon pemimpin pada kartu suara dengan benar dan 2 anak masih mencontreng pada 2 gambar sekaligus pasangan calon. Sehingga skor akhir pada siklus I adalah 52 nilai yang masih sangat rendah dari KKM yang diinginkan peneliti yaitu 80, untuk itu peneliti melaksanakan perbaikan dengan tindakan penggunaan Strategi Viral Desi pada Siklus II. 


\section{Siklus II}

Dalam kegiatan perbaikan pada siklus II, peneliti membuat skenario pemilihan ketua kelas dengan tata cara seperti pelaksanaan Pemilu. Peneliti memutarkan video tutorial tata cara pemilihan ketua kelas melalui youtobe dan meminta siswa untuk mendemonstrasikan sesuai skenario yang disusun peneliti di kelas, perbaikan di siklus II dilaksanakan pada hari Senin 19 Oktober 2020, baik peneliti maupun kolaborator mencatat segala aktifitas peserta didik Tunagrahita di kelas XI SMALB dan diperoleh data sebagai berikut:

Tabel 3. Rekapitulasi Hasil Ketepatan Mencotreng Siswa pada Kartu Suara Siklus II

\begin{tabular}{|c|c|c|c|c|c|}
\hline \multirow{2}{*}{ No } & Nama & \multirow{2}{*}{ L/P } & \multicolumn{2}{|c|}{ Ketepatan Mencontreng } & \multirow{2}{*}{ Nilai } \\
\hline & Siswa & & 1 Paslon & 2 Paslon & 80 \\
\hline 1 & Indra & L & $\sqrt{ }$ & & 80 \\
\hline 2 & Syahrul & L & $\sqrt{ }$ & & 80 \\
\hline 3 & Fida & P & $\sqrt{ }$ & & 80 \\
\hline 4 & Laila & P & $\sqrt{ }$ & & 80 \\
\hline 5 & Lala & P & $\sqrt{ }$ & & $400 / 5 \times 100=80$ \\
\hline \multicolumn{7}{|c|}{ Rata-rata } \\
\hline
\end{tabular}

Sumber : Hasil Penelitian, diolah (2020)

Keterangan:

1. Siswa mencontreng pada 1 gambar paslon dengan benar mendapat skor 80

2. Siswa mencontreng pada 2 gambar paslon mendapat skor 10

Pada perbaikan di siklus II, 5 siswa mampu mencontreng 1 gambar pasangan calon ketua kelas pada kartu suara dengan benar. Sehingga skor akhir pada siklus II adalah 80 sesuai dengan KKM yang diinginkan peneliti yaitu 80, untuk itu peneliti menyimpulkan bahwa strategi Video Tutorial dan Demonstrasi (Viral Desi)dapat meningkatkan pemanahaman penggunaan kartu suara dalam sistem demokrasi di Indonesia bagi siwa Tunagrahita jenjang SMALB di SLB Empat Lima Babat kecamatan Babat Kabupaten Lamongan.

Gambar 2. Grafik Ketercapaian Strategi Viral Desi mulai dari Pra Siklus, Siklus I dan Siklus II

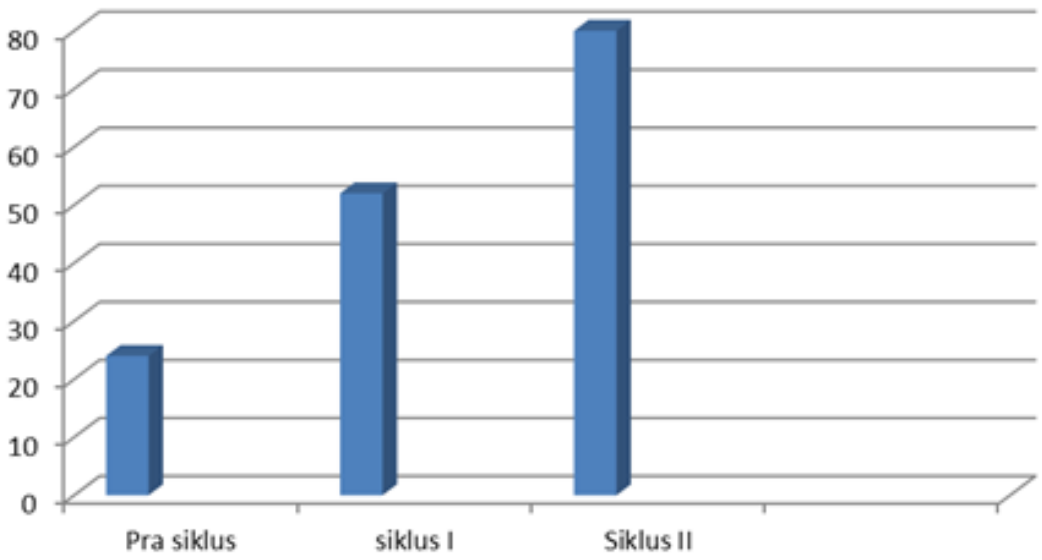

Sumber : Hasil Penelitian, diolah (2020)

Keterangan: Pada grafik di atas menunjukkan perubahan skor ke arah lebih baik, diawali dari pra siklus anak anak mendapatkan skor rata-rata 24 nilai yang 
sangat rendah sekali, kemudian pada siklus I mendapatkan skor rata-rata 52 itupun masih jauh dari KKM yang diharapkan, kemudian dilakukan perbaikan dengan melaksanakan tindakan lebih intensif pada siklus ke II, dan memperoleh skor ratarata 80 .

\section{KESIMPULAN DAN SARAN \\ Kesimpulan}

Berdasarkan hasil tindakan serta pembahasan dalam penelitian ini dapat ditarik kesimpulan bahwa strategi VIRAL DESI (Video Tutorial dan Demontrasi) dapat meningkatkan pemahaman siswa SMALB Empat Lima Babat Kecamatan Babat Kabupaten Lamogan" dalam penggunaan hak suara dalam sistem demokrasi Indonesia".

\section{Saran}

Pemerintah dalam hal ini melalui Komisi Peilihan Umum (KPU) mengadakan sosialisasi tata cara menggunakan kartu suara bagi anak-anak disabilitas, yang sudah memasuki usia 17 tahun agar dapat ikut berpartisipasi memberikan aspirasi suaranya terhadap pemilihan wakil-wakil rakyat dalam ajang pesta demokrasi di Indonesia.

\section{DAFTAR PUSTAKA}

Kustiatun Widianingsih. 2018. Mereka Yang Istimewa Yang Berkarya, Surabaya: CV Pustaka Media Guru

Miles, Huberman, 2009, Analisis Data Kualitatif, Jakarta: Universitas Indonesia

Nugroho, Taufiq, 2014, Modul Sosialisasi Pemilu untuk Difabel, Sragen: Komisi Pemilihan Umum Daerah Sragen

Soekanwo, ariani, 2009, Buku Panduan pemilu Akses Penyandang Cacat 2009, Jakarta: sekretariat PPUA Penca

Undang-Undang Dasar Negara Republik Indonesia

Undang-Undang no 7 tahun 2017 tentang pemilihan umum

UU nomor 19 tahun 2011 tetang Ratifikasi Konvensi PBB mengenai Hak-Hak Penyandang Disabilitas

UU RI Nomor 4 Tahun 1997 tentng Penyandang Cacat 